
A C T A

Andrzej MAMCARZ, Eugenia MURAWSKA

\author{
STUDIES ON THE LARVAE AND FRY FEEDING OF THE TWO \\ COREGONIDAE SPECIES DURING ITS FIRST YEAR OF GROWTH \\ IN ILLUMINATED CAGES
}

\author{
STUDIA NAD ODŻYWIANIEM SIĘ LARW I NARYBKU DWU GATUNKÓW \\ RYB GLAZBIELOWATYCH (COREGONIDAE) \\ PODCZAS PIERWSZEGO ROKU PODCHOWU W SADZACH OS'WIETLONYCH
}

\author{
Department of Fishery, \\ Agricultural and Technical Academy in Olsztyn
}

\begin{abstract}
Feeding character of the $0+$ age Coregonidae, in cages, depends on the quantitative and qualitative composition of organisms during spring and autumn plactonic growth peaks. Planctonic growth peak in spring supports energetic needs of fish larvae and with light applied to concentrate plankton, enables to get a large amount of stocking material. An autumn one seems to be insufficient for covering the Coregonidae fry energetic needs. The character of Coregonus lavaretus L. and Coregonus peled Gmel. larvae and fry feeding is discussed, including differences in natural environment as well as changes during succesive seasons of growth.
\end{abstract}

\title{
INTRODUCTION
}

In Poland, surveys on the Coregonidae growth in the illuminated lake cages have carried out since 1973 (Brylinski et al., 1975, Radziej et al., 1978). It brought into general use an original method of stocking material production, based on feeding fish with zooplankton. allured, into cages, by the light. Growth effectiveness depends, however, to a great extend, on a type of the lake and seasonal changes of zooplankton biomass(Bryliński et al.,1979; Mamcarz and Szczerbowski, 1984). On the basis of the up to date surveys it was stated, that small eutrophic basins with high and stabilized nutritional resources are to be chosen for production, in cages, purpose (Radziej et al., 1978). It does not exclude the possibility of fish rearing in the less nutritious lakes. However, it requires 
both, recognition of its nutritional basis and nutritional needs of fishes in cages, and rearing adjustment to these conditions. As yet this subjest has been recognised only slightly.

The presented work gives analysis of the feeding pattern of Coregonus lavaretus L. and Coregonus peled Gmel. larvae and fry in illuminated cages placed in the lake of an average nutritional conditions.

\section{EXPERIMENTAL AREA}

The Leginskie Lake (228.3 ha) is a vendace basin in Northern Poland (gathering ground of Łyna and Pregoła) with maximal depth of $37.2 \mathrm{~m}$. According to Olszewski and Więcławska (1965) this is the lake between meso- and eutrophy type. The whole summer there is a thermal stratification with cold $\left(6\right.$ to $\left.9^{\circ} \mathrm{C}\right)$ and stable hypolymnion. The water temperature, within epilimnion, exceeds $14^{\circ} \mathrm{C}$ in May and drops below this temperature in September. An oxygen content, in surface layer, does not drop below $6 \mathrm{mg} / \mathrm{dm}^{3}$, with over oxygenation up to $120-130 \%$, noted ussually in summer. The characteristic feature is only slight changes of chemical composition of the water. Annually, there are 16 species of rotifers, 4 species of copepods and 13 species of cladocerans in zooplankton. Ratatoria state for 65 to $75 \%$ of zooplankton, while Copepoda 17 to $27 \%$ and Cladocera 3 to $15 \%$ (Mamcarz, 1982). Dominants among rotifers are Keratella. Asplanchna and Polyarthra spp. Within the copepods group, juvenile forms are most numerous, with Eudiaptomus graciloides dominating among the adult individuals. The most common cladocerans are Daphnia cucullata and Bosmina spp.

\section{MATERIAL AND METHODS}

To determine changes within a nutritional ground of the lake, samples of zooplankton were collected outside the cages in a day-and a night- time. In 1977, samples from inside the cages were also collected in a day time. The plankton samples were collected by the $5 \mathrm{dm}^{3}$ Ruttner's sampler, every $1 \mathrm{~m}$ below the surface down to the cage submersion level $(5 \mathrm{~m})$. When caught, organisms were seeved through a planktonic net and classified. Zooplankton biomass was estimated according to the below given equations:

Where:

$$
\begin{array}{ll}
\text { for Copepodes } & W=55 \mathrm{~L}^{2.73} \\
\text { for Daphnidae } & W=52 \mathrm{~L}^{3.012},
\end{array}
$$

$\mathrm{W}-$ is weight in $\mu \mathrm{g}$ and $\mathrm{L}-$ length in mm (Hillbricht-Ilkowska and Patalas, 1967). Biomass of rotifers as well as other rarely noted species was estimated according to the weight standards.

The Coregonidae rearing methods, growth rate and survival of both tested species and the environmental conditions were presented, in details, in previous works (Mamcarz and Szczerbowski, 1984; Szczerbowski and Mamcarz, 1984). 
To test a composition of food, samples were collected, in succesive rearing years (from May to December 1977-1979), from cages of initial concentration of larvae per $1 \mathrm{~m}^{3}$ equal to 12500,3750 and 6250, respectively (Coregonus peled $\mathrm{Gmel}$ ), and 5832 of C. lavaretus L. larvae $/ \mathrm{m}^{3}$ (in 1977). Two to three times a month 10 to 20 individuals were being fished from to cages, at random, as to test contents of its alimentary tracts. Fishes were kept in $4 \%$ formalin; its total length measured, with the $1 \mathrm{~mm}$ accuracy, and weight determined (larvae with $1 \mathrm{mg}$ and fry with $1 \mathrm{~g}$ accuracy). Next alimentary tract of each individual was carefully analysed for its content. A total number of organisms of each category was estimated as an average number of preys per fish. Share of each category was estimatec' quantitatively and energetically.

An average energetical value of food ( $E$ in mcal) was estimated according to the method of van Densen (1985). For each planktonic organisin a relation between the body length and energy (LE), according to Vijverberg and Frank (1976) was applied. For Daphnia cucullata and for Bosmina longirostris, the above given relation estimated by the authors, respectively, for Daphnia hyalina and Bosmina coregoni, was applied. For sporadically noted representatives of Diaphanosoma species the relation LE for Daphnia was used. Energetic value of Eudiaptomus graciloides was calculated due to LE relation for Eurytemora affinis. Nauplia and rotifers were not measured. Its energetical values were taken from van Densen (1985).

Electivity index in fishes for various zooplankton taxa were calculated according to the Ivlev equation (1977):

$$
I=\frac{r_{i}-p_{i}}{r_{i}-p_{i}}
$$

where:

$r_{i}$ - share of $i-$ category of prey in the alimentary tract, in percent,

$\mathrm{p}_{\mathrm{i}}$ - share of $\mathrm{i}$ - category of prey in the lake, in percent.

Analysis were conducted on 630 larvae and fry of Coregonus peled Gmel. and 233 individuals of Coregonus lavaretus $\mathrm{L}$.

\section{RESULTS}

Changes in zooplankton biomass in the lake and cages.

During the whole year, excluding the spring growth peak, zooplankton biomass in the lake was lower than $2 \mathrm{~g} / \mathrm{m}^{3}$, (Fig. 1). In May and June the highest concentration of planktonic organisms was noted, with its biomass reaching 7 to $16 \mathrm{~g} / \mathrm{m}^{3}$. Daphnia cucullata and Bosmina longirostris dominated in zooplankton that time (over $80 \%$ of the biomass). There was an increase, in the planktonic organisms biomass, noted outside the cages during the night-time, up to $16-18 \mathrm{~g} / \mathrm{m}^{3}$. The increase caused mainly by a selective attraction of Cladocera, by the light. During summer stagnation there was a rapid decline in biomass noted, caused by a reduction of cladoceran number in 

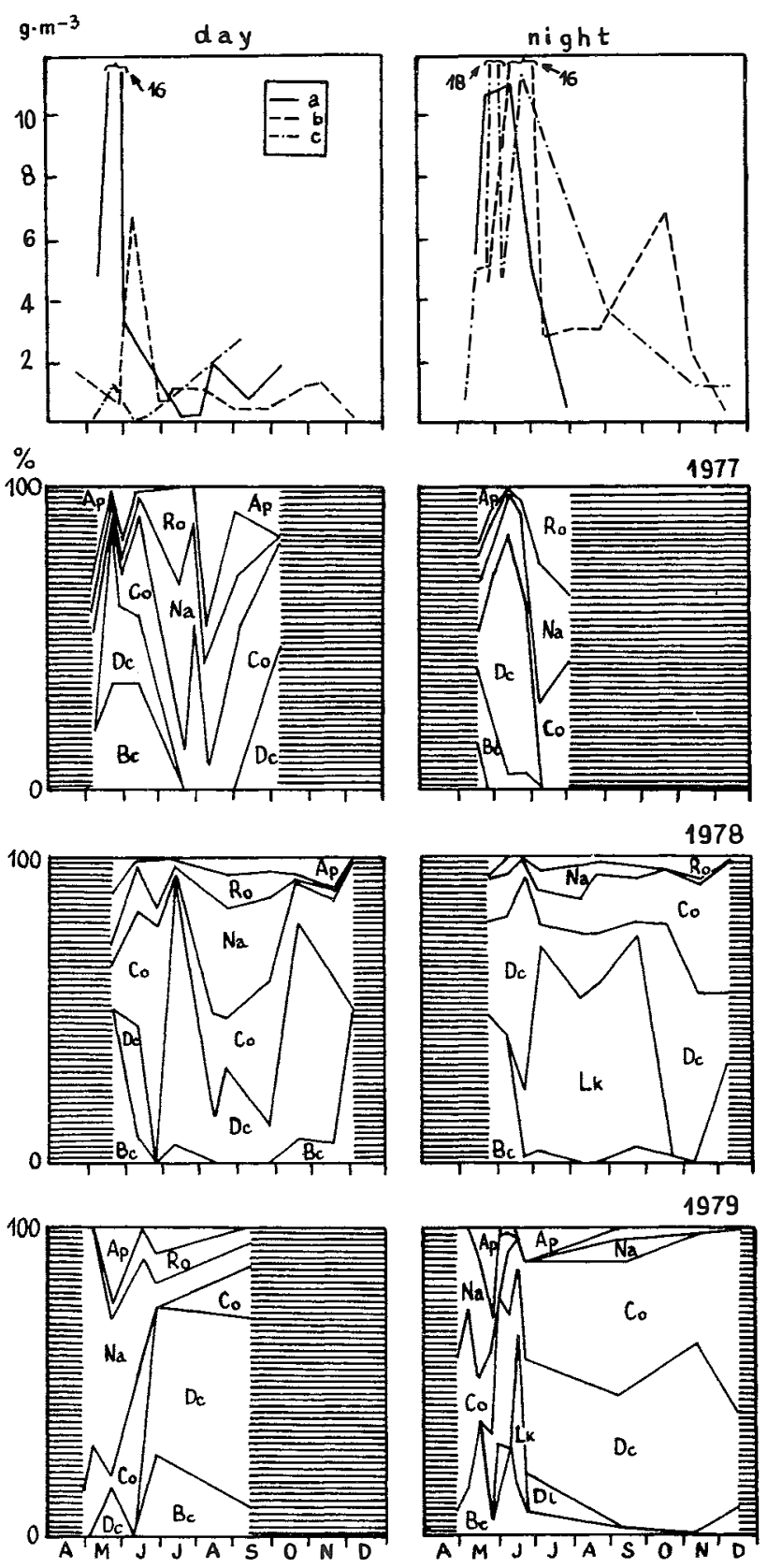

Fig. 1. Biomass and zooplankton composition, in percentage, outside the cages, at the day and the night time, in 1977 to 1979 . From the bottom to the top sequence:

$\mathrm{Bc}=$ Bosmina coregoni, $\mathrm{Lk}=$ Leptodora kindti, $\mathrm{Dc}=$ Daphnia cucculata, $\mathrm{D} 1=$ Daphnia longispina, $\mathrm{Co}=$ Copepoda, $\mathrm{Na}=$ nauplia, $\mathrm{Ap}=$ Asplanchna priodonta, $\mathrm{Ro}=$ other rotifers.

Years: $\mathrm{a}=1977, \mathrm{~b}=1978, \mathrm{c}=1979$ 
Table 1

Prey (in numbers per fish) of Coregonus lavaretus larvae and fry in day (D) and night $(\mathrm{N})$ from illuminated cages located in Lake Leginskie in 1977

Notations: $\quad \mathrm{Ro}=$ rotifers, $\mathrm{Na}=$ nauplia, $\mathrm{Co}=$ copepodites, $\mathrm{Me}=$ Mesocyclops adults,

$\mathrm{Eu}=$ Eudiaptomus adults, $\mathrm{Bo}=$ Bosmina $s p ., \mathrm{Da}=$ Daphnia $s p ., \mathrm{Ld}=$ Leptodora kindt $i$

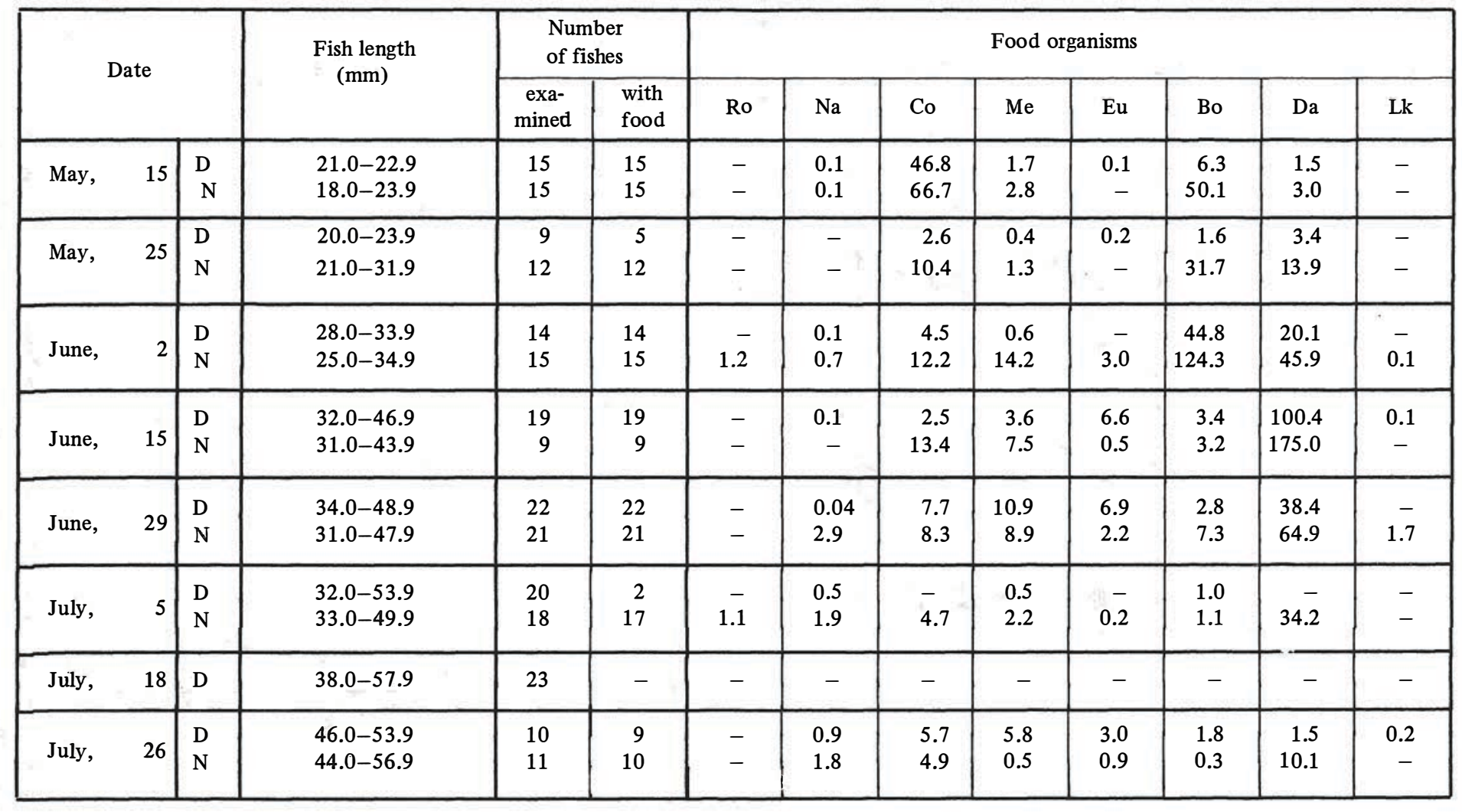



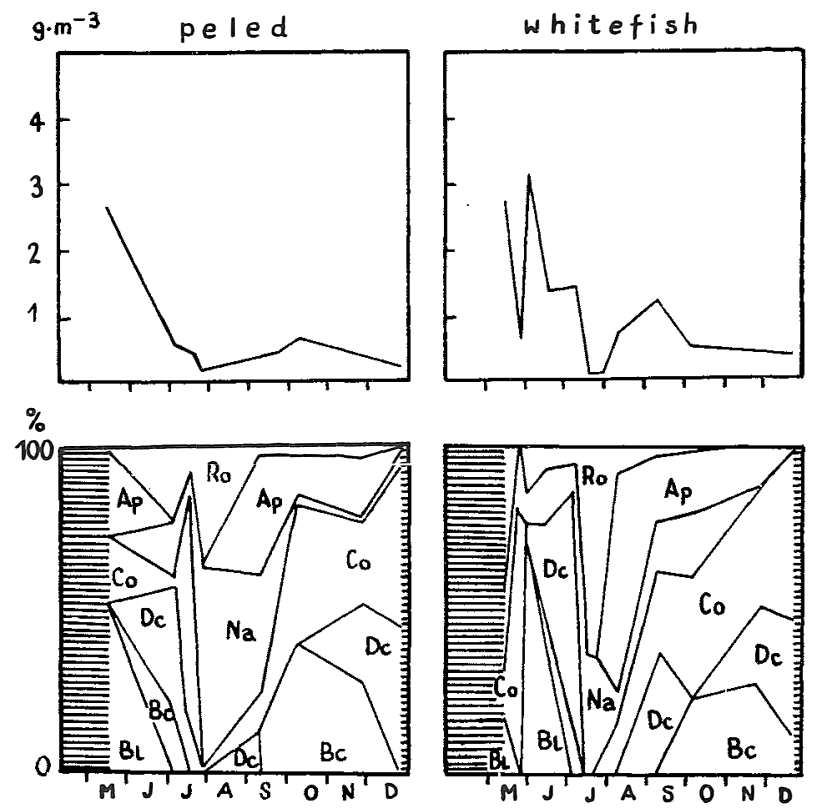

Fig. 2. Biomas and zooplankton composition, in percentage in cages with Coregonus lavaretus L. and Coregonus peled Gmel. day time samples, in 1977. Sequence and strips of components as on Fig.1

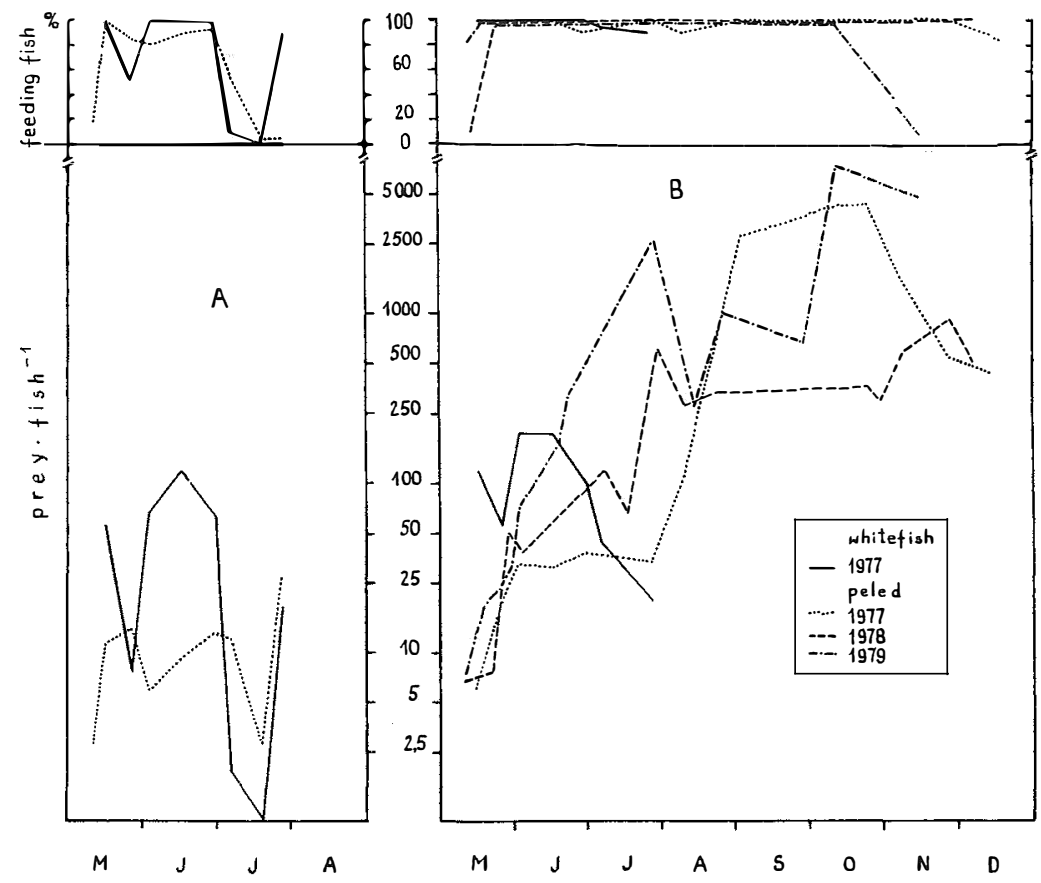

Fig. 3. An average number of prey in the alimentary tract of Coregonus lavaretus L. and Coregonus peled Gmel. during the day time (A) and the night time (B) and percent of preying fishes (upper part of figure) 
zooplankton. Main components of plankton that time were rotifers and juvenile Copepodes (nauplia), which created an exceptionally unconvinient nutritional situation for fish in cages. Since August a steady increase in Cladocera number in fish prey was noted. As for Eudiaptomus graciloides, dominated among the Copepoda species, two growth peaks were noted (in may and in autumn). Asplanchna priodonta, dominant among rotifers, reached over $2 \mathrm{~g} / \mathrm{m}^{3}$ in biomass, in May.

During the day time zooplankton biomass in cages do not differ essentially from the one in the lake (Fig. 2). In the night time a visible increase in number of prey, in cages, was observed, despite an intensive preying of fish (Szczerbowski and Mamcarz, 1984).

\section{Food of Coregonus lavaretus $L$. in cages.}

There was a fast increase in number of organisms in the Coregonus lavaretus L. larvae alimentary tracts in May and June 1977, when the maximum multiplication of zooplankton was observed (Table 1). Number of prey grew up from 50 individuals per fish during the day time preying in the middle of May, to 100 individuals per fish in the middle of June (Fig. 3). During that time the larvae size increased, in average, from 21.3 to $38.6 \mathrm{~mm}$. In May, the main component of the Coregonus lavaretus L. larvae food were copepods, replaced fast by cladocerans such as Bosmina coregoni and Daphnia cucullata (Fig. 4). Since the end of June, when Cladocera disappeared from zooplankton, Coregonus lavaretus $\mathrm{L}$. stopped on feeding during the day time. In some still preying individuals, however, separate grown up Copepoda and its nauplia were present,

In the night time number of planktonic organisms within the alimentary tracts of Coregonus lavaretus L. was almost twice that high as in the day time (Fig. 3). Increase in number of the two dominating, both quantitatively and energetically, cladocerans, in fish food, was even greater (Fig. 4). By the end of June some juvenile individuals of Leptodora kindti were isolated from the fish food. The fish did not stop feeding in the night time during the drastic drop of Cladocera number in zooplankton, however there was a visible decrease in number of organisms in its alimentary tracts down to 15-25 individuals per fish (Fig. 3). There were only few fishes with totally empty alimentary tracts. A maximal energetic value of food taken by Coregonus lavaretus L. was alike during the day and the night time and equal to $\sim 1$ cal per individual (Fig. 5). Essential differences were noted in July, when energetic value of food, in the right, was about $0.1 \mathrm{cal} /$ individual, while in the day time there was no food in the fish alimentary tracts.

Feeding of Coregonus peled Gmel. in cages.

Feeding of Coregonus peled Gmel., in illuminated cages, was somewhat different than the one of Coregonus lavaretus $\mathrm{L}$. Until the middle of May larvae were not preying, utilizing reserves of yolk sack. Since then, a fast increase in number of organisms in its alimentary tracts was observed, however, to a manifold lower level, than the one noted for Coregonus lavaretus $\mathrm{L}$. (Table 2,3,4). During the day time preying number of prey taken incresed from about 2,5 individuals/fish, in the middle of May, up to 
15 individuals/fish at the end of May; being doubled during the night time preying (Fig. 3). The larvae size increased from 11 up to $14.8 \mathrm{~mm}$. The day time rations were dominated, at the beginning, by Rotatoria (mainly Keratella and Kellicottia species), replaced, by the end of month by cladocerans Bosmina coregoni and Daphnia cucullata (Fig. 6). Share of Rotatoria during the night time preying, reached its minimum, being
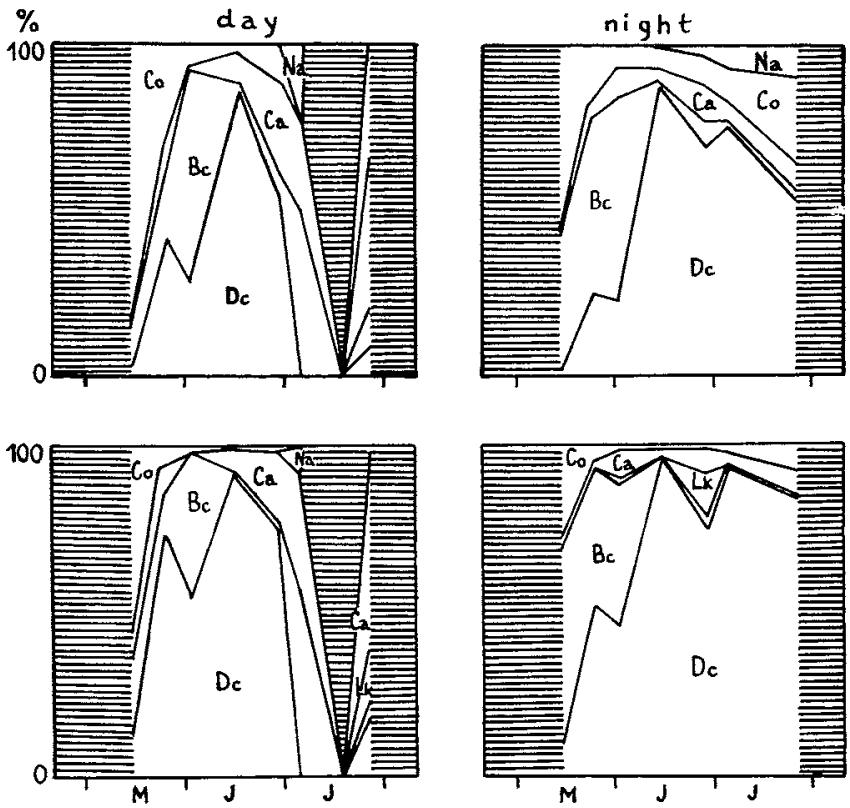

Fig. 4. Quantitative (above) and energetic (beneath) composition of zooplankton within the Coregonus lavaretus L. food during spring season 1977. From the bottom to the top: $\mathrm{Dc}=$ Daphnia cucullata, $\mathrm{Bc}=$ Bosmine coregoni, $\mathrm{Lk}=$ Leptodora kindti, $\mathrm{Ca}=$ Copepoda adults Co kopepodits, $\mathrm{Na}=$ nouplia
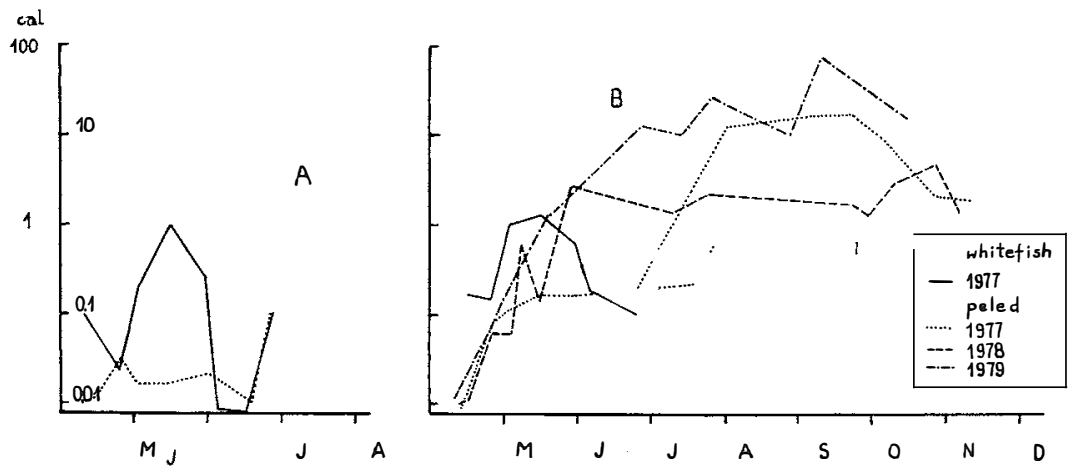

Fig. 5. Energy (cal) of an average amount of prey consumed by the Coregonus lavaretus $L$. and Coregonus peled Gmel. in the day time (A) and the night time (B), illuminated cages, during the first year of life 
Prey (in numbers per fish) of Coregonus peled larvae and fry in day (D) and night (N) from illuminated cages located in Lake Leginskie in 1977 Notations as in Table 1

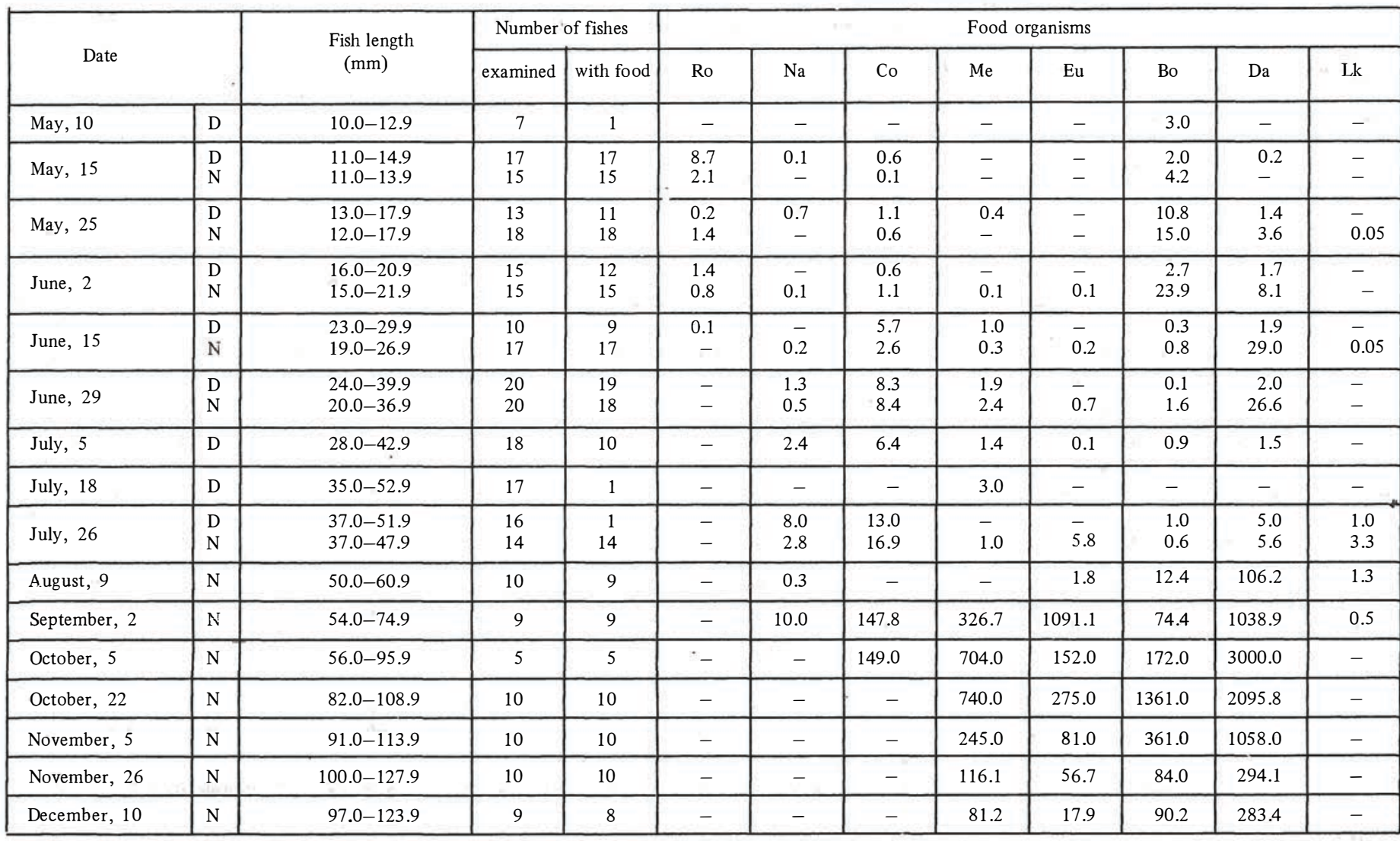


Prey (in number per fish) of Coregonus peled larvae and fry in night from illuminated cages located in Lake Leginskie in 1978 Notations as in Table 1; By = Bythotrephes $s p$.

\begin{tabular}{|c|c|c|c|c|c|c|c|c|c|c|c|c|}
\hline \multirow{2}{*}{ Date } & \multirow{2}{*}{$\begin{array}{l}\text { Fish length } \\
(\mathrm{mm})\end{array}$} & \multicolumn{2}{|c|}{$\begin{array}{l}\text { Number } \\
\text { of fishes }\end{array}$} & \multirow[b]{2}{*}{ Ro } & \multirow[b]{2}{*}{$\mathrm{Na}$} & \multirow[b]{2}{*}{ Co } & \multirow[b]{2}{*}{$\mathrm{Me}$} & \multirow[b]{2}{*}{$\mathrm{Eu}$} & \multirow[b]{2}{*}{ Bo } & \multirow[b]{2}{*}{$\mathrm{Da}$} & \multirow[b]{2}{*}{ Lk } & \multirow[b]{2}{*}{ By } \\
\hline & & $\begin{array}{l}\text { ex.a- } \\
\text { mined }\end{array}$ & $\begin{array}{l}\text { with } \\
\text { food }\end{array}$ & & & & & & & & & \\
\hline May, 10 & $10.0-11.9$ & 15 & 2 & - & - & 3.5 & - & - & 3.5 & - & - & - \\
\hline May, 15 & $10.0-12.9$ & 12 & 11 & 0.2 & 0.6 & 4.2 & - & - & 0.1 & 0.1 & - & - \\
\hline May, 25 & $15.0-18.9$ & 20 & 20 & 2.2 & - & 0.6 & - & - & 19.9 & 1.4 & - & - \\
\hline June, 3 & $23.0-26.9$ & 10 & 10 & 0.5 & 7.0 & 19.5 & - & - & 13.0 & 0.3 & - & - \\
\hline June, 7 & $27.0-31.9$ & 10 & 10 & - & 1.2 & 23.3 & 2.9 & 4.2 & 26.0 & 63.9 & 0.5 & - \\
\hline June, 16 & $26.0-35.9$ & 12 & 12 & 0.5 & 3.1 & 39.6 & 1.1 & - & 9.7 & 15.6 & - & - \\
\hline June, 28 & $33.0-42.9$ & 15 & 15 & - & 0.7 & 53.1 & - & 26.9 & 38.1 & 515.0 & - & - \\
\hline August, 9 & $37.0-53.9$ & 10 & 10 & - & 1.6 & 80.8 & 28.3 & 69.4 & 2.3 & 94.9 & 11.3 & - \\
\hline August, 23 & $43.0-58.9$ & 11 & 11 & - & - & 58.6 & 11.4 & 95.3 & 0.9 & 79.6 & 30.4 & 75.2 \\
\hline October, 23 & $65.0-86.9$ & 7 & 7 & - & - & - & 137.1 & 21.3 & 35.0 & 196.6 & - & 0.7 \\
\hline October, 28 & $70.0-88.9$ & 10 & 10 & - & - & - & 106.0 & 14.9 & 45.2 & 149.4 & - & - \\
\hline November, 8 & $73.0-96.9$ & 10 & 10 & - & - & - & 121.0 & 114.0 & 36.0 & 336.0 & - & 0.5 \\
\hline November, 26 & $89.0-105.9$ & 10 & 10 & - & - & - & 262.0 & 125.0 & 19.0 & 513.0 & - & - \\
\hline December, 5 & $90.0-107.9$ & 10 & 10 & - & - & - & 445.5 & 8.0 & 14.5 & 39.0 & 0.5 & - \\
\hline
\end{tabular}


Prey (in numbers per fish) of Coregonus peled larvae and fry in night illuminated cages located in Lake Leginskie in 1979 located in Lake Leginskie in 1979

\begin{tabular}{|c|c|c|c|c|c|c|c|c|c|c|c|c|c|}
\hline \multirow{2}{*}{ Date } & \multirow{2}{*}{$\begin{array}{l}\text { Fish length } \\
\quad(\mathrm{mm})\end{array}$} & \multicolumn{2}{|c|}{ Number of fish } & \multicolumn{10}{|c|}{ Food organisms } \\
\hline & & $\begin{array}{c}\text { exa- } \\
\text { mined }\end{array}$ & $\begin{array}{l}\text { with } \\
\text { food }\end{array}$ & Ro & $\mathrm{Na}$ & Co & $\mathrm{Me}$ & $\mathrm{Eu}$ & Bo & $\mathrm{Da}$ & $\mathrm{Lk}$ & By & $\mathrm{Ve}$ \\
\hline May, 11 & $10.0-12.9$ & 6 & 5 & 0.4 & 5.6 & 1.8 & - & - & - & 0.2 & - & - & \\
\hline Māy, 17 & $12.0-14.9$ & 10 & 10 & 0.1 & 14.1 & 5.0 & - & - & - & 0.1 & - & - & \\
\hline May, 29 & $19.0-24.9$ & 10 & 10 & 0.9 & 0.7 & 6.2 & 5.4 & 3.1 & 3.0 & 13.6 & - & - & \\
\hline June, 3 & $23.0-25.9$ & 10 & 10 & - & 0.3 & 8.2 & 0.8 & - & 40.4 & 29.6 & 0.2 & - & \\
\hline June, 18 & $23.0-35.9$ & 10 & 10 & - & 0.4 & 14.9 & 17.6 & 32.6 & 7.0 & 100.8 & 8.1 & - & \\
\hline June, 22 & $32.0-44.9$ & 10 & 10 & - & - & 5.3 & 7.0 & 211.7 & 50.9 & 69.8 & 1.1 & - & \\
\hline June, 27 & $53.0-65.9$ & 10 & 10 & - & 0.3 & 1.5 & 3.6 & 1.0 & 1.4 & 89.4 & - & - & 2443 \\
\hline August, 13 & $67.0-92.9$ & 10 & 10 & - & 1.1 & - & 39.9 & 4.1 & 4.7 & 67.9 & 160.9 & 0.1 & \\
\hline September, 27 & $118.0-140.9$ & 10 & 10 & - & - & 30.5 & 356.9 & 9.6 & 63.6 & 117.0 & 102.0 & 57.6 & \\
\hline October, 10 & $129.0-174.9$ & 7 & 7 & - & - & 194.3 & 1485.7 & 46.4 & 3035.7 & 2002.8 & 740.0 & 196.4 & \\
\hline November, 13 & $132.0-168.9$ & 6 & 1 & - & - & - & 882.4 & 52.0 & 306.0 & 3606.0 & - & 2.0 & \\
\hline
\end{tabular}


replaced by the juvenile forms of Copepoda. Due to changes in zooplankton composition, changes in relations between the Coregonus peled Gmel. food components, in successive years, were noted. (Fig. 6 and 7). Energetic value of Coregonus peled Gmel. food, taken in May, in the day time did not exceed 0.05 cal level, increasing up to about $0.1 \mathrm{cal} /$ individual in the night time (Fig. 5).

In the successive years of Coregonus peled $\mathrm{Gmel}$. rearing its character of feeding, during the summer stagnation in the lake, was changing. During the day time number of prey ranged from 5 to 10 individuals/fish, droping down to 2.5 individuals/fish in July (Fig. 3). Energetic value of that food was lower than $0.05 \mathrm{cal} /$ individual (Fig. 3) with Copepoda copepodits playing the main role in that food (Fig. 6).

A night time preying character of Coregonus peled Gmel. was influenced greatly by relations between the planktonic organisms, under the cladocerans deficit. In 1977, almost throughout the whole summer stagnation, number of prey taken by Coregonus peled Gmel. was stabilized at the level of about 25 individuals/fish (Fig. 3). Main components were Daphnia cucullata and copepodits of Copepods (Fig. 6). Next year, a dynamic increase in number of prey from about 50 (at the end of May) up to about 500 individuals at the end of July) per alimentary tract of Coregonus peled Gmel. was
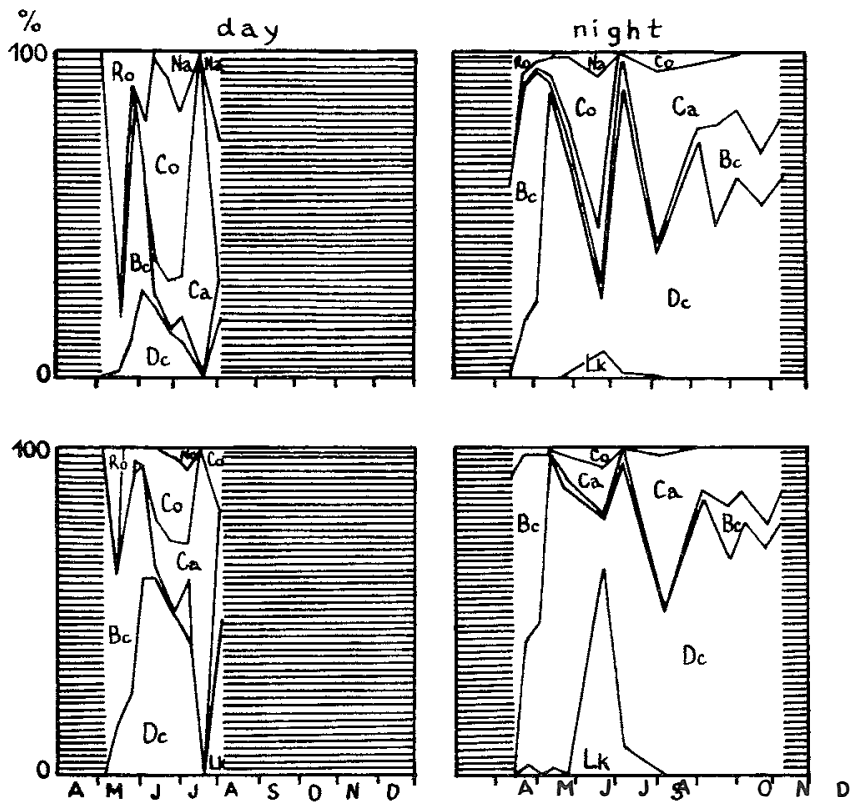

Fig. 6. Quantitative (above) and energetic (beneath) composition of zooplankton within the Coregonus peled Gmel. food in 1977. From the bottom to the top: Lk = Leptodora kindti $\mathrm{Dc}=$ Daphnia cucullata, $\mathrm{Bc}=$ Bosmina coregoni, $\mathrm{Ca}=$ Copepoda adults, $\mathrm{Co}=$ kopepodits, $\mathrm{Na}=$ nauplia, Ro $=$ rotifers. 
observed. The food was enriched by a quantitative and energetic share of Copepoda (mainly copepodits and adults individuals of Eudiaptomus graciloides/and Leptodora kindti (Fig. 7). By the end of July, 1979, number of prey caught reached its maximum level of about 2500 individuals per fish. That time Coregonus peled $\mathrm{Gmel}$. was feeding mostly on Dreissena polymorpha veligers- attached to an experimental platform- and on Leptodora kindti (Table 4). In effect an energetic value of food taken by the fish, during successive experimental years, was quite variable. At the end of July it ranged from 0,2 to $10 \mathrm{cal} /$ individual (Fig. 5). Those differences influenced the fish growth, which, during the time of experimental rearing, reached $41.8 ; 49.9$ and $60.7 \mathrm{~mm}$ in, respectively, : :977; 1978 and 1979.

Differences in the quantitative and qualitative composition of the Coregonus peled Gmel. food were visible also in autumn seasons 1977--1979. Number of planktonic organisms taken ranged from 250 (in 1977) to over 5000 individuals (in 1979) per fish (Fig. 3). Energetic value ranged, respectively, from 1 to about 100 cal per individual (Fig. 5). Prevailing part of food, both quantitatively and energetically, were cladocerans, such as: Daphnia cucullata, Leptodora kindti, Bosmina coregoni and Bythotrephes longimanus (Fig. 6 and 7). Essential were also copepods - Eudiaptomus graciloides.
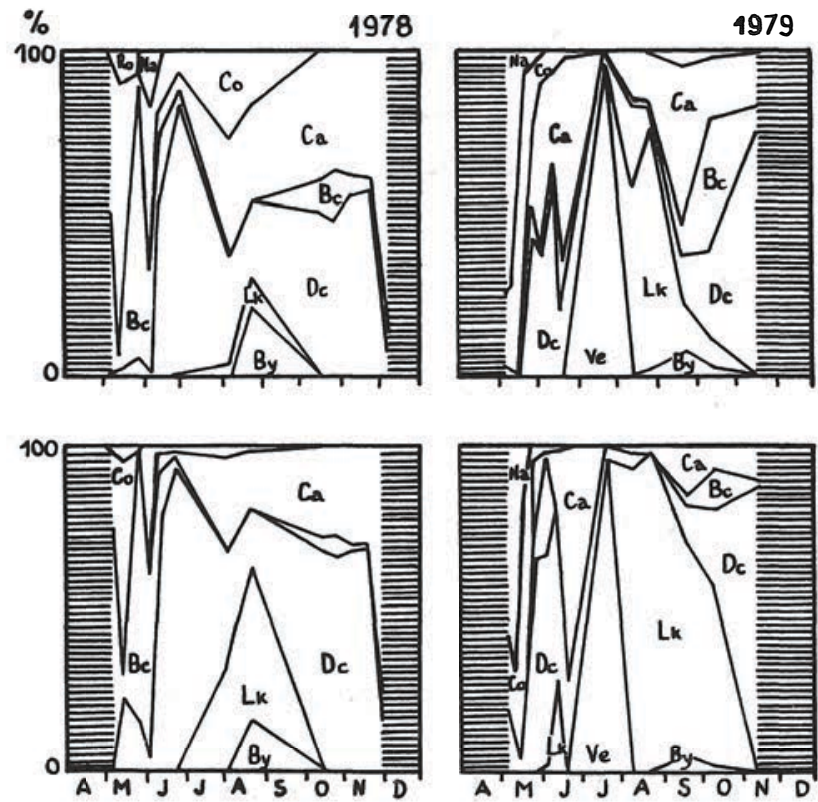

Quantitative (above) and energetic (beneath) composition of zooplankton within the Coregonus peled Gmel. food, in 1978 and 1979. From the bottom to the top: By = Bythotrephes longimanus, $\mathrm{Lk}=$ Leptodora kindti, $\mathrm{Ve}=$ veligers of Dreissena polymorpha, $\mathrm{Dc}=$ Daphnia cucullata, $\mathrm{Bc}=$ Bosmina coregoni, $\mathrm{Ca}=$ Copepoda adults, $\mathrm{Co}=$ kopepodits, $\mathrm{Na}=$ nauplia, $\mathrm{Ro}=$ rotifers. 
Table 5

Electivity index in Coregonus lavaretus L. and Coregonus peled Gmel. for the main zooplankton taxa during day (D) and night (N) feeding in cages (May - July 1977)

Notations: $\quad \mathrm{Ro}=$ Rotatoria, $\mathrm{Na}=$ nauplia, $\mathrm{Co}=$ copepodits, $\mathrm{Cy}=\mathrm{Cyclopidae}$,

$\mathrm{Dia}=$ Diaptomidae, $\mathrm{Bo}=$ Bosminidae, $\mathrm{Da}=$ Daphnidae, $\mathrm{Lk}=$ Leptodora kindti

\begin{tabular}{|c|c|c|c|c|c|c|c|c|c|c|}
\hline & Mo & & Ro & $\mathrm{Na}$ & Co & $\mathrm{Cy}$ & Dia & Do & $\mathrm{Da}$ & $\mathrm{Lk}$ \\
\hline \multirow{3}{*}{ 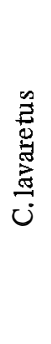 } & May & $\begin{array}{l}\mathrm{D} \\
\mathrm{N}\end{array}$ & $\begin{array}{l}-1.0 \\
-1.0\end{array}$ & $\begin{array}{l}-0.94 \\
-0.99\end{array}$ & $\begin{array}{l}+0.86 \\
+0.89\end{array}$ & $\begin{array}{l}+0.38 \\
+0.23\end{array}$ & $\begin{array}{l}-0.80 \\
-1.0\end{array}$ & $\begin{array}{l}+0.43 \\
+0.84\end{array}$ & $\begin{array}{l}-0.24 \\
+0.26\end{array}$ & $\begin{array}{l}0.0 \\
0.0\end{array}$ \\
\hline & June & $\begin{array}{l}\mathrm{D} \\
\mathrm{N}\end{array}$ & $\begin{array}{l}-1.0 \\
-0.98\end{array}$ & $\begin{array}{l}-0.97 \\
-0.79\end{array}$ & $\begin{array}{l}+0.01 \\
+0.12\end{array}$ & $\begin{array}{l}+0.26 \\
-0.21\end{array}$ & $\begin{array}{r}+0.78 \\
-0.44\end{array}$ & $\begin{array}{l}+0.60 \\
+0.88\end{array}$ & $\begin{array}{l}+0.94 \\
+0.13\end{array}$ & $\begin{array}{l}-0.50 \\
+1.0\end{array}$ \\
\hline & July & $\begin{array}{l}\mathrm{D} \\
\mathrm{N}\end{array}$ & $\begin{array}{r}-1.0 \\
-0.95\end{array}$ & $\begin{array}{l}-0.31 \\
-0.31\end{array}$ & $\begin{array}{l}+0.93 \\
+0.84\end{array}$ & $\begin{array}{l}+0.99 \\
+0.70\end{array}$ & $\begin{array}{l}+0.90 \\
+0.70\end{array}$ & $\begin{array}{l}+1.0 \\
+1.0\end{array}$ & $\begin{array}{l}+1.0 \\
+1.0\end{array}$ & $\begin{array}{r}+1.0 \\
0.0\end{array}$ \\
\hline \multirow{3}{*}{$\begin{array}{l}\frac{0}{0} \\
\frac{0}{2} \\
\dot{\Sigma}\end{array}$} & May & $\begin{array}{l}\mathrm{D} \\
\mathrm{N}\end{array}$ & $\begin{array}{l}-0.27 \\
-0.71\end{array}$ & $\begin{array}{l}-0.43 \\
-1.0\end{array}$ & $\begin{array}{l}+0.02 \\
+0.04\end{array}$ & $\begin{array}{r}0.0 \\
+1.0\end{array}$ & $\begin{array}{l}-1.0 \\
+1.0\end{array}$ & $\begin{array}{l}+0.80 \\
+0.89\end{array}$ & $\begin{array}{l}-0.14 \\
+0.47\end{array}$ & $\begin{array}{r}0.0 \\
+1.0\end{array}$ \\
\hline & June & $\begin{array}{l}\mathrm{D} \\
\mathrm{N}\end{array}$ & $\begin{array}{l}-0.89 \\
-0.87\end{array}$ & $\begin{array}{l}-0.15 \\
-0.83\end{array}$ & $\begin{array}{l}+0.78 \\
+0.36\end{array}$ & $\begin{array}{l}+0.46 \\
-0.57\end{array}$ & $\begin{array}{l}-1.0 \\
-0.56\end{array}$ & $\begin{array}{l}+0.38 \\
+0.84\end{array}$ & $\begin{array}{l}+0.80 \\
+0.18\end{array}$ & $\begin{array}{l}-1.0 \\
+1.0\end{array}$ \\
\hline & July & $\begin{array}{l}\mathrm{D} \\
\mathrm{N}\end{array}$ & $\begin{array}{l}-1.0 \\
-1.0\end{array}$ & $\begin{array}{l}+0.35 \\
-0.12\end{array}$ & $\begin{array}{l}+0.96 \\
+0.95\end{array}$ & $\begin{array}{l}+0.96 \\
+0.55\end{array}$ & $\begin{array}{l}-0.19 \\
+0.97\end{array}$ & $\begin{array}{l}+1.0 \\
+1.0\end{array}$ & $\begin{array}{l}+1.0 \\
+1.0\end{array}$ & $\begin{array}{l}+1.0 \\
+1.0\end{array}$ \\
\hline
\end{tabular}




\section{Electivity}

Electivity coefficient values, calculated for May, are erroneous to some extend, because size of larvae snout, influencing its feeding poscibilities at the preliminary stage of growth, was not taken into consideration. In the following months, when larvae could catch all kind of prey and when the $r_{i}$ and $p_{i}$ values were high, the electivity coefficient was more reliable.

Both tested Coregonidae species showed positive electivity towards cladocerans and Cyclopidae in the day and the night time as well (Table 5). Together with the fich size growth an increase of the electivity coefficient value, up to maximum $(+1,0)$, was observed. Electivity towards Diaptomidae was variable and changed from positive to negative due to a seasonal dynamic of copepods and its reaction to light. Practically, throughout the whole rearing period, in cages, fishes showed negative olectivity towards rotifers and nauplia of copepods (Table 5 and 6). A character of the electivity changes towards individual zooplankton groups was very simillar for both reared Coregonidae species.

\section{DISCUSSION}

Results of many surveys done by other authors indicate, that insufficient number and quality of food, available for the Coregonidee larvae causes its high mortality due to starvation. A critical period in the larvae life, when changing a source of energy from interior one to food from an environment, creates the survival possibilities for individuals, living under various nutritional conditions (Jezierska et al. 1978, 1979; Grudniewski, 1980). During ontogenesis, there are fast developmental changes in: morphological and anatomic features, alimentary tract, swimming abilities and larvae behaviour (Stroband and Dąbrowski, 1979; Mähr et al. 1983; Dabrowski, 1986; Mamcarz, 1988). Together with an increase of energetic needs, there is a rapid increase in larvae' demand for food. According to Geisler (1953) a minimal daily nutrition dosis for the vendace hatch was equal to about 40,80 and 150 nauplia in the first, second and third week of age, respectively. According to Braum (1967), during the first three days, at the temperature $11^{\circ} \mathrm{C}$, a 10 -hours food ration of Coregomus wertmonni increases from 13 to 44 individuals of zooplankton. Einsele, cited by Kriegsmana (1970), publishes, that the Coregorus lavaretus L larvae feeding demands increases from about 500 organisms, per individual of $20 \mathrm{~mm}$ in length, up to 1000 organisms for fish of $30 \mathrm{~mm}$ in length. Studies of Hoagman (1974) suggest the feeding minimum for Coregonus chupeaformis to be 10 to 20 planktonic organisms per day, at the water temperature $14.4^{\circ} \mathrm{C}$. According to Dąbrowski's (1976) calculations, Coregonus lavaretus $\mathrm{L}$. larvae consumes daily, during its first 16 days of life, 80 to 97 organisms of zooplankton, at the temperature $13.5^{\circ} \mathrm{C}$. All the above cited results, obtained at various laboratories for various fish species and nutrition, approach life conditions and larvae feeding strategy in nature. . Some data on feeding of Coregonidae larvae in natural 
Table 6

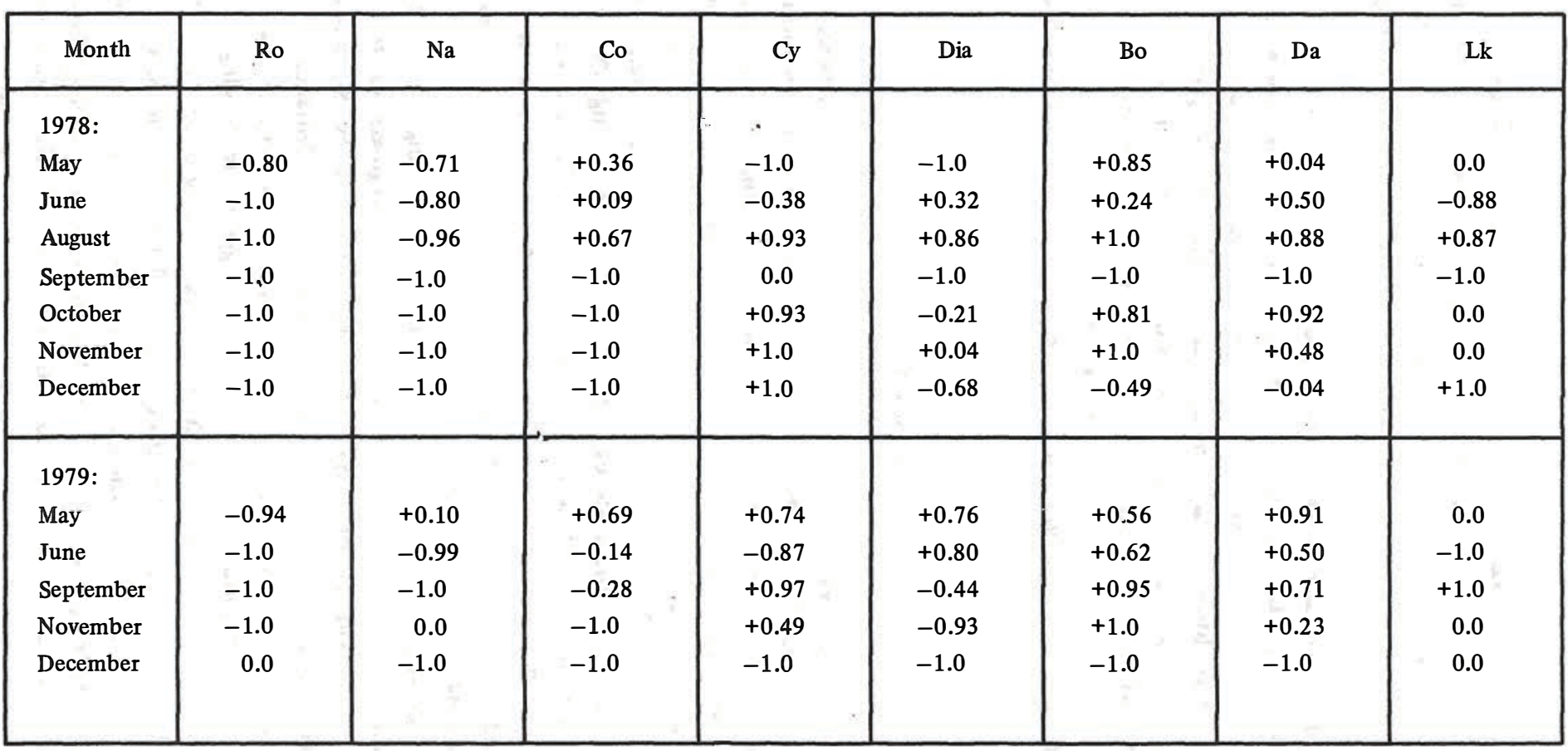


environment (Lindström, 1962; Salojärvi, 1979; Dąbrowski et al. 1984; Huusko et al. 1988) proves a number of planktonic organisms taken by one fish is very variable and ussually lower than the one calculated experimentally. It is influenced, in between, by uneven distribution of zooplankton (Salojärvi, 1979; Ponton and Müller, 1987), light conditions (Hoagman, 1974) and other factors. Even a slight changes in zooplankton concentration result in a high variability in larvae survival (Taylor and Freedberg, 1984). Under such conditions a feeding selectivity reflects not only larvae needs but also its possibilities (Hoagman, 1973; Hartmann, 1986; Niesslbeck and Klein, 1988).

Larvae rearing, in the illuminated cages, where, attracted by the light, zooplankton is concentrated, creates a very convenient feeding situation for larvae. Practically all planktonic organisms are directing towards the light source, giving huge concentrations during its maximum growth season. It is essential for an increase in larvae survival, due to minimalization its energetic loses, when seeking for food in the critical period of life. A feeding strategy of Coregonidae, reared in cages, also changes. Under natural conditions a character oflarvae feeding changes a lot due to availibility of planktonic organisms (Lindström, 1970; Naesje et al. 1986). However, nauplia and copepodits of copepods are the basic prey (Flüchter, 1980; Salojärvi, 1979; Dąbrowski et al. 1984; Niesslbeck and Klein,1988). Together with an increase of food concentration, larvae select bigger prey (Rajasilta and Vuorinen, 1983) and grow faster (Korovina et al. 1975). From the very first weeks, there is a strongly underlined pression on greater organisms noted, if only a larvae snout size is big enough. Already in May, number of consumed cladocerans reaches 50 to 100 individuals/fish. Nauplia and copepodits of copepods lose, in cages, its priority in fish feed, and its significance for fish increases when availability of Cladocera is limited.

During the whole rearing time, in cages, a negative electivity of Coregonus lavaretus $\mathrm{L}$. and Coregonus peled Gmel. towards nauplia was observed. Nutritional meaning of Rotatoria, under those conditions, is even less pronounced. Larvae of Coregonus peled Gmel., bigger at the moment of hatching, did not accept rotifers from the beginning, however smaller ones consumed rotifers at the first two months in small numbers. Individuals from Keratella and Polyarthra species were the main prey, although, which is interesting, Asplanchna dominated both; quantitatively and in size. Lack of interest in rotifers during rearing of Coregonidae larvae in cages and a natural environment, was noted by the others/Marciak et al. 1976; Marciak, 1979; Salojärvi, 1979; Dąbrowski et al. 1984). A sporadic come back to the same type of feeding resulted from a compulsory situation (Hoagman, 1973; Marciak, 1979; Fliichter, 1982).

A particular role, in the formation of intensive feeding competition, accompanied by an increased fish mortality, in cages, played periods of decreases in copepods number due to its seasonal dynamics (June-July). An increased feeding pression of Coregonidae on all bigger zooplanktonic organisms present in the cages, including such atypical as veligers of Dreissena polymorpha, was noted then. A reflaction of feeding 
relations in cages, when some fishes were starving, was increase in size variability and in condition of individuals (Mamcarz, 1984).

Right from the beginning of an autumn homothermy, nauplia were of no nutritional value for Coregonidae reared in cages. There was a drop in copepodites share, as well, replaced by a maximum pression on Cladocera and adults copepods. During autumn, there was, also, an increase in number of prey taken, exceeding, often, level of 5.000 to 7.000 individuals/fish. The Coregonus peled Gmel. fry feeding ration ranged, in the successive years of rearing, from 1 to $100 \mathrm{cal} / \mathrm{fish}$. Even in 1979 rations were below the data possible to be obtained under the natural conditions. According to Tichomirova (1978), a feeding ration of Coregonus peled Gmel fry in the Vrevo Lake was $0.288 \mathrm{kcal} /$ individual. Dmitrenko (1978) stated, that to reach the weight $4.2-30.0 \mathrm{~g}$ Coregonus peled Gmel. needs 33.1-150 kcal/individual, which converted to food, respond to 52-254 g. An energetic maximum for Coregonus lavaretus L., determined by Giussani and Bernardi (1977), equal to $2550 \mathrm{cal}$ per individual, was noted at the end of August. According to that, an autumn rearing in cages does not seem to cover the nutritional needs of Coregonidae.

Under the natural conditions several essential changes in type of Coregonus lavaretus L. and Coregonus peled Gmel. feeding were noted. An increase in amount of food taken is being accompanied by a drop in efectiveness of using it for growth (Gordeeva et al. 1975; 1976, Sterligov et al. 1977). Besides, there is an increased pressure : on big Cladocera organisms (Grimaldi, 1972; Giussani, 1974), with a feeding spectrum enriched in benthos organisms (Loskutova and Solovov, 1969; Naesje et al. 1986; Novoselov, 1987). It is not possible to be done in cages, that is why fishes are dependent on an autumn developmental peak of Cladocera. It dictates the limits to productive possibilities, because under such conditions number of individuals in cages are to be minimal.

\section{SUMMARY}

Studies on feeding of larvae and fry $0+$ of two Coregonidae species (Coregonus lavaretus $\mathrm{L}$. and Coregonus peled $\mathrm{Gmel}_{\text {.) }}$ reared in illuminated cages, in lake of an average feeding resources, were carried out. A quantitative and qualitative composition of fish food, taken during the day and a night time, was tested, as well as fish electivity towards various zooplanktonic categories and energetic value of an average feeding ration per fish.

It was stated, that fish feeding characteristic, in cages, is dependent on the organisms composition in the spring and autumn planktonic peaks. The first prey of Coregonus lavaretus L. larvae are nauplia and copepodites while for Coregonus peled $\mathrm{Gmel}$. rotifers and juvenile copepods. In succesive rearing months an increasing pressure of Coregonidae towards big planktonic forms (cladocerans and adult copepods) is noted. Together with the fish growth there is an increase in number of consumed organisms per individual, up to 5.000-7.000 organisms during autumn season. The parallel increase of energetic value of the taken food takes place. Besides essential fluctuations in quality, quantity and energetic value of zooplankton available for fish in cages, in succesive rearing seasons. An autumn planktonic summit does not cover the nutritional needs of fish, that is why rearing continuation up to an autumn is being uneffective. 
The differences in the nature of the both fish species feeding were discussed and obtained results were compared to the ones for fish feeding in natural environment.

\section{REFERENCES}

Braum E, 1967: The survival of fish larvae in reference of their feeding behaviour and the food supply. - Biological basis of freshwater fish production. Oxford, Blackwell Sci. Publ.: 113-131.

Brylinsłld E., Uryn B., Radziej J., 1975: Wychơw materiału zarybieniowego koregualdów w ofwietlanych sadzach jeziorowych [Rearing of the Coregonidae stocking material in illuminated itse cages]. IRS Olsztyn, 87: 1-10.

Bryliriski E., Radziej J., Uryn B., 1979: Podchów wylegu i narybku siei (Coregonus lavaretus L.) w ofwietlonych sadzach jeziorowych. [Rearing of the Coregonus lavaretus L. larvae and fry in illuminated lake cages]. - Rocz. Nauk RoL, H-99-3: 55-77.

Dąbroweri K., 1976: How to calculate the optimal density of food for fish larvae. - Environ. Biol. Fish., 1: 87-89.

Dąbrowelo K., 1986: Active metabolism in larval and juvenile fish: ontogenetic changes, effect of water temperature and fasting. - Fish. Physiol. Biochem., 3: 125-144.

Daprowelo K., Murewsla E., Textoct J., Wielgoes S., 1984: Studies on the feeding of Coregonus pollan (Thompson) alevins and fry in Lough Neagh. - Int. Revue ges. Hydrobiol, 4: 529-540.

Dmitrenko JuJu, 1978: Piscevye potrebnosti segoletkov sigovych i nel'my vyrascivaemych v oremych pitomnikach - Ryb. Choz. Mosk., 9: 31-31. (in Russian.

Flïchter J., 1980: Review of the present knowledge of rearing whitefish (Coregonidae) larve. Aquaculture, 19: 191-208.

Flüchter J., 1982: Aufzucht von Renkenbesatz in Teichen. - Fischwirt, 8: 57-60.

Geissler R., 1953: Über Nahnung und Nahrungsbedarf von Marthenbrut. - Fischwirt, 3: 372-376.

Gius:ni G., 1974: Planctofagia selettiva del coregone "bondella" (Coregonus sp.) del Lago Maggione. - Mem. Ist. Ital. Idrobiol. 31: 181-203.

Giusani G., de Bemardi R., 1977: Food selectivity in Coregonus sp. of Lago Maggiore: an energetical approach - Mem. Inst. Ital Idrobiol, 34: 121-130.

Gordeeva L.N., Novoselcev G.E., Stertigov A.V., 1975: Isopokovane pirca as rost tholodju siga v reerach pitomnikach. - Osnovy bioprod. vnutr. wod. Pribaltiki, Vilnius, Mintis: 58-59 (in Russian)

Gordeeva L.N., Novoselcev G.E., Sterligov A.V., 1976: Pitanie molodi siga (Coregonus lavaretus L.) i osobennosti ispokovanija energii pisci na rost. - Izv. NIORCh, 118 68-66 (in Russian)

Grimaldi E., 1972: Transcurabile ruolo dei Copepodi nel regime altinentare dei pesci planctofaghi del Lago Maggiore. - Riv. Ital. Piscic. Ittiopatol., 1: 3-5.

Grudriewski Cz, 1980: Wpływ głodowania na przeżywalność wylęgu sielawy (Coregonus albula L.), siei (Coregonus lavaretus L.) i pelugi (Coregonus peled Gmel.). [Effect of starvation on suivival of larvae of Coregonus albula L., Coregonus lavaretus L. and Coregonus peled Gmel. ] - Zesz. nauk. ART Olsztyn, 10: 3-38.

Hartmann J., 1986: Interspecific predictors of selected prey of young fishes - Engebn. Limnol, 22: 373-386.

Hillbricht-Ilkowska A, Patalns K, 1967: Metody oceny prodikcji i biomasy oraz niektóre problemy metodyki ilościowej zoophanktonu. [Methods of production and biomass estimation and some aspects of quantitative analysis of zooplankton ]. - Ekol. pol., B series, 13, 2: 139-171.

Hoagman WJ., 1973: The hatching, distribution, abundance, growth, and food of the larval lake whitefish (Coregonus clupeaformis Mitchill) of the Central Green Bay, Lake Michigan. - Rep. Inst. Freshwater Res. Drottn. 53: 1-20.

Hogman W.J., 1974: Vital activity paraneters as related to the early life history of larval and post-larval lake whitefish Coregonus clupeafomis - The early life history of fish, Berlin, Heidelberg, New York, Springer Verlag: 547-558. 
Huusko A., Sutela T., Karjalainen J., Auvinen H., Alasaarela E., 1988: Food of vendace (Coregonus albula L.) fry in a natural lake and in a regulated lake in Northern Finland. - Finnish Fish. Res. 9: 447-456.

Ivlev V.S., 1977: Eksperimentalnaja ekologija pitanija ryb. - Kiev, Naukova Dumka. (in Russian)

Jezierska B., Korwin-Kossakowski M., Jówko G., 1978: Influence of starvation on whitefish (Coregonus lavaretus L.) larvae. - Verh. Internat. Verein. Limnol., 20: 2134-2136.

Jezierska B., Korwin-Kossakowski M., Jówko G., 1979: The effect of starvation and temperature conditions on vendace (Coregonus albula L.) larvae. - Pol. Arch. Hydrobiol., 26, 3: 387-395.

Korovina V.M., Lebedeva L.I., Maksimova L.P., Privodina V.P., 1975: Pitanije, rost i rozvitije licinok čira v raznych uslovjach. - Izv. NIORCh, 104: 152-179. (in Russian)

Kriegsman F., 1970: Jungfischaufzucht mit Zooplankton. - Fischwirt. 20: 184-188.

Lindström T., 1962: Life history of whitefish young (Coregonus) in two lake reservoirs. - Rep. Inst. Freshwater Res., Drottn. 44: 113-144.

Lindström T., 1970: Habitats of whitefish in some north Swedish lakes at different stages in life history. - Biology of Coregonid Fishes, Univ. of Manitoba Press: 461-479.

Loskutova G.I., Solovov V.V., 1969: O pitanii peljadi (Coregonus peled Gmelin) v ozere Dolgom (Altajskij kraj). - Gidrobiol. Żurn., 6: 101-103. (in Russian)

Mähr K., Grabner M., Hofer R。, Moser H., 1983: Histological and physiological development of the stomach in Coregonus sp. - Arch. Hydrobiol., 98: 344-353.

Mamcarz A., 1982: Zmienność cech biometrycznych pelugi (Coregonus peled Gmelin, 1788) podczas jej chowu w sadzach jeziorowych. [Variability in biometric features of Coregonus peled Gmel., during its rearing in lake cages]. Inst. Icht. and Fishery, ART Olsztyn, a Ph.D. thesis.

Mamcarz A., 1984: Rearing of coregonid fishes (Coregonidae) in illuminated lake cages. III. Phenotypic variability in body size of Coregonus peled Gmel., during the first year. - Aquaculture, 40: 241-250.

Mamcarz A., 1988: The development of schooling behaviour in coregonid larvae in the illuminated cages. - Finnish Fish. Res. 9: 323-328.

Mamcarz A., Szczerbowski J.A., 1984: Rearing of coregonid fishes (Coregonidae) in illuminated lake cages. I. Growth and survival of Coregonus lavaretus L. and Coregonus peled Gmel., - Aquaculture, 40: $135-145$.

Marciak Z., Uryn B., Zachwieja J., 1976: Warunki oraz wyniki podchowu narybku koregonidów w oświetlonych sadzach toniowych. [Conditions and results of Coregonidae fry rearing in illuminated cages]. - Gosp. ryb., 4:6-9.

Marciak Z., 1979: Food preference of juveniles of three coregonid species reared in cages. - Europ. Mar. Soc., Spec. Publ., 4: 127-137.

Naesje T.F., Sandlund O.T., Jonsson B., 1986: Habitat use and growth of age-O whitefish, Coregonus lavaretus, and cisco, C. albula. - Env. Biol. Fish., 4: 309-314.

Niesslbeck P., Klein M., 1988: Growth conditions of naturally hatched and artificially bred larvae of Coregonus lavaretus in Lake Starnberg (Bavaria, FRG). - Finnish Fish. Res. 9: 361-372.

Novoselov A.P., 1987: Piß̌̌evye otnoß̌enija introducirovannoj peljadi Coregonus peled s predstaviteljami mestnoj ichtiofauny v uslovijach ozera i reki Archangel'skoj oblasti. - Vopr. Ichtiol., 3: 458-465.

Olszewski P., Więcławska M., 1965: Chemizm wód jezior Legińskich. [Water chemism of Leginskie Lakes]. - Zesz. nauk. WSR Olsztyn, 20: 292-304.

Ponton D.,Müller $\mathbb{R}_{\text {, }}$ 1987: Distribution and food of larval and juvenile Coregonus sp. in Lake Sarnen (Switzerland)。 - Finnish Fish. Res。 9: 117-125.

Radziej J., Korycki A., Pyka J., 1978: Podchów wylęgu i narybku pelugi w oświetlonych sadzach jeziorowych. [Rearing of the Coregonus peled Gmel. larvae and fry in illuminated lake cages]. Gosp. ryb., 5: 3-5.

Rajasilta M., Vuorinen I., 1983: A field study of prey selection in planktivorous fish. lairvae. Oecologia (Berlin), 59: 65-68. 
Salojärvi K., 1979: Food availability and conditions for whitefish larvae (Coregonus lavaretus s..) in the lakes drained by the Oulujoki. - Thind Europ. Ichthyol. Congress, Warsaw, 18-25.09.1979.

Sterligov A.V., Jułkova G.V., Novoselcev G.E., 1977: Pitanie i piscevye potrebnosti segoletkov jamnogo siga v ðzzernom pitomnike. - Biol. mutr. vod., Inform. bjul, 33: 41-45. (in Russian)

Stroband H.W.J., Dalbrowelk K., 1979: Morphological and physiological aspects of the digestive system and feeding in fresh-water fish larvae. - Nutrition de Poissons. CNERNA, Paris, 5: 355-376.

Szczerbowski J.A., Mancarz A., 1984: Rearing of coregonid fishes (Coregonidae) in illuminated lake cages. II. Environmental conditions during fish rearing. - Aquaculture, 40: 147-161.

Taylor W.W., Freeberg M.H. 1984: Effect of food abundance on larval lake whitefish, Coregonus clupeaformis Mitchill, growth and survival. - J. Fish. Biol, 25: 733-741.

Tichomirova L.P., 1978: Vozrastnaja izmencivost pixcevych racionov peljadi ozera Vrevo. Ryboch. izux. vnutr. vod., 23: 10-13. (in Russian)

Van Densen W.L.T., 1985: Feding behaviour of major $0+$ fish species in a shallow, eutrophic lake (Tjeukemeer, The Netherlands). - Z. arigew. Ichthyol, 2: 49-70.

Viverberg J., Frank T.H, 1976: The chemical composition and energy contents of fresthwater copepods and cladocerans in relation to their size. - Freshrwat. Biol., 6: 333-345.

Translated: Dr. E. Daczkowska-Kozon

Andzej Mamcarz, Eugenin Mrrawska

\section{STUDIA NAD ODŻYWIANIEM SIE LARW I NARYBKU DWU GATUNKóW RYB GLĄBIELOWATYCH (COREGONIDAE) PODCZAS PIERWSZEGO ROKU PODCHOWU W SADZACH OSWIETLONYCH}

\section{STRESZCZENIE}

Badano odżywianie sie larw i narybku of dwu gatunkơw Coregonidae (Coregonus lavaretus L. i Coregonus peled $G$ mel.) podczas podchowu w sadzach ofwietlonych w warunkach jeziora $o$ przeciętnej zasobności pokarmowej. Określano skład ilościowy i jakościowy polarnnu ryb w czasie dnia i nocy, elektywność w stosunku do ró̇inych kategorii zooplanktonu a także wartość energetyczną sredniej racji pokarmowej przypadają ja jedną rybę.

Stwierdzono, że o charakterze odżywiania się ryb w sadzach decyduje skład organizmów w wiosennym $\mathrm{i}$ jesiennym szczycie planktonowym. Pierwszym pokarmein larw siei sq nauplii $\mathrm{i}$ kopepodity, natomiast u pelugi wrotki i młodociane stadia widłonogow. W kolejnych miesiącach podchowu wzrasta zdecydowanie presja Coregonidae na duze formy planktonowe (wioslarki i dorosłe widłonogi), wraz ze wzrostem ryb zwiększa się ilość organizmów konsumowanych w przeliczeniu na jednego osobnika aź do 5-7 tysięcy sztuk w okresie jesiennym. Odpowiednio do tego warasta wartość energetyczna zjadanego pokarmu. Wykazano znaczne wahania w jakości, ilości i wartości energetycznej zooplanktonu przypadajacego na ryby w sadzach w kolejnych sezonach podchowu. Jesienny szczyt planktonowy nie zabezpiecza już potrzeb pokarmowych ryb, w zwiqzku z tym kontynuowanie podchowu do jesieni jest nieefektywne. Omówiono róinice $w$ charakterze odżywiania się obu gatunków a alize porównano uzyskane wynili $z$ informacjami o odżywianiu się ryb w śodowisku naturalnym.

Author's address:

Received: 1988.03:10

Dr. Andrzej Mamcarz

Katedra Rybactwa

Alademia RolniczoTechniczna

10-957 Olsztyn-Kortowo

Polsian (Paland) 